\title{
Communication
}

\section{The Xanthomonas RaxH-RaxR Two-Component Regulatory System Is Orthologous to the Zinc-Responsive Pseudomonas ColS-ColR System}

\author{
Valley Stewart ${ }^{1, *}$ and Pamela C. Ronald ${ }^{2}$ \\ 1 Department of Microbiology \& Molecular Genetics, University of California, Davis, CA 95616, USA \\ 2 Department of Plant Pathology and Genome Center, University of California, Davis, CA 95616, USA; \\ pcronald@ucdavis.edu \\ * Correspondence: vjstewart@ucdavis.edu
}

check for updates

Citation: Stewart, V.; Ronald, P.C. The Xanthomonas RaxH-RaxR Two-Component Regulatory System Is Orthologous to the

Zinc-Responsive Pseudomonas ColS-ColR System. Microorganisms 2021, 9, 1458. https://doi.org/ $10.3390 /$ microorganisms 9071458

Academic Editors: Vincenzo Scarlato and Davide Roncarati

Received: 4 June 2021

Accepted: 2 July 2021

Published: 7 July 2021

Publisher's Note: MDPI stays neutral with regard to jurisdictional claims in published maps and institutional affiliations.

Copyright: (c) 2021 by the authors. Licensee MDPI, Basel, Switzerland. This article is an open access article distributed under the terms and conditions of the Creative Commons Attribution (CC BY) license (https:// creativecommons.org/licenses/by/ $4.0 /)$.

\begin{abstract}
Genome sequence comparisons to infer likely gene functions require accurate ortholog assignments. In Pseudomonas spp., the sensor-regulator ColS-ColR two-component regulatory system responds to zinc and other metals to control certain membrane-related functions, including lipid A remodeling. In Xanthomonas spp., three different two-component regulatory systems, $\mathrm{RaxH}-$ RaxR, VgrS-VgrR, and DetS-DetR, have been denoted as ColS-ColR in several different genome annotations and publications. To clarify these assignments, we compared the sensor periplasmic domain sequences and found that those from Pseudomonas ColS and Xanthomonas RaxH share a similar size as well as the location of a Glu-X-X-Glu metal ion-binding motif. Furthermore, we determined that three genes adjacent to $\operatorname{rax} \mathrm{RH}$ are predicted to encode enzymes that remodel the lipid A component of lipopolysaccharide. The modifications catalyzed by lipid A phosphoethanolamine transferase (EptA) and lipid A 1-phosphatase (LpxE) previously were detected in lipid A from multiple Xanthomonas spp. The third gene encodes a predicted lipid A glycosyl transferase (ArnT). Together, these results indicate that the Xanthomonas RaxH-RaxR system is orthologous to the Pseudomonas ColS-ColR system that regulates lipid A remodeling. To avoid future confusion, we recommend that the terms ColS and ColR no longer be applied to Xanthomonas spp., and that the Vgr, Rax, and Det designations be used instead.
\end{abstract}

Keywords: ColS-ColR; RaxH-RaxR; VgrS-VgrR; lipid A remodeling; lipid A phosphoethanolamine transferase; lipid A 1-phosphatase; Xanthomonas oryzae pv. oryzae

\section{Introduction}

Diverse Xanthomonas species and pathovars cause serious diseases in most plants [1,2]. One example is X. oryzae pv. oryzae (Xoo), which causes significant rice crop losses in Asia and Africa [3]. Resistance to Xoo is conferred by the rice XA21 receptor kinase [4], which activates innate immune responses upon binding the Xoo RaxX (required for activation of XA21 component X) protein [5]. RaxX is a secreted sulfopeptide similar to the plant PSY sulfopeptide growth hormone [6,7], and is synthesized by some but not all Xanthomonas spp. [8].

Xoo proteins required specifically for RaxX processing and secretion are encoded by the $\operatorname{raxX}$-raxSTAB gene cluster [5,9-11] (Figure 1). These genes are adjacent to a seven-gene cluster including the raxHR genes [12], which encode the sensor histidine kinase and response regulator proteins, respectively, of a two-component regulatory system [12,13]. Phosphoryl transfer from a sensor to its cognate response regulator increases DNA binding in order to control target gene transcription initiation [14-16]. Truncated soluble RaxH protein rapidly autophosphorylates and catalyzes efficient phosphoryl-transfer to RaxR protein in vitro [13] as expected for a cognate two-component regulatory pair [17]. To date, the RaxR protein has not been demonstrated to bind DNA or activate transcription. 


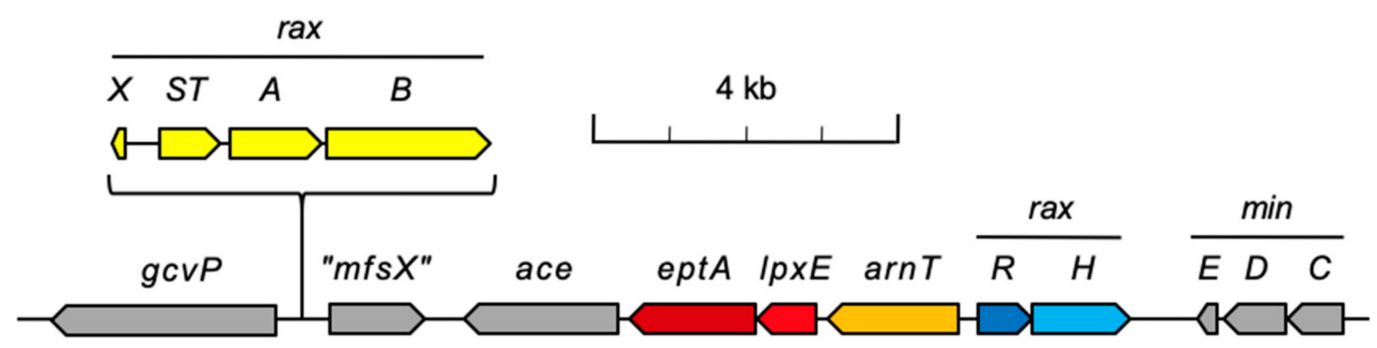

Figure 1. Genes in the Xoo strain PXO99 ${ }^{\mathrm{A}}$ gcvP-minCDE region. Drawn to scale. Gene symbols are ept $A$, phosphoethanolamine transferase (dark red); lpxE, lipid A 1-phosphatase (red); arnT, sugar-undecaprenyl phosphate transferase (orange); $\operatorname{raxR}$ (dark blue); $\operatorname{raxH}$ (light blue). Other gene symbols are described in the text. The $\operatorname{raxX}$-raxSTAB gene cluster is between $g c v P$ and " $m f x S$ " only in certain Xanthomonas species (Table S1). Small open reading frames with unknown function are not shown. See text for references.

Pseudomonas spp. encode the ColS-ColR two-component regulatory system, identified initially in P. fluorescens as required for root colonization through controlling functions that remodel LPS (lipopolysaccharide) [18,19]. In Xanthomonas spp., three separate twocomponent regulatory pairs have been denoted as ColS-ColR in several different published genome sequences [20-26] and research papers [27-30]. Separately, each of these Xanthomonas ColS-ColR-like pairs has been assigned unique symbols based on experimental analysis: RaxH-RaxR [12], VgrS-VgrR (virulence and growth regulator) [31], and DetS-DetR (detoxifying) [32].

In Xoo, the RaxH-RaxR pair may play a role in setting the level of RaxX synthesis, processing, or secretion through a mechanism not yet determined [12]. In Xoo, Xanthomonas campestris pv. campestris (Xcc), and X. citri (Xac), the VgrS-VgrR pair controls virulence, the hypersensitive response, environmental stress tolerance, and growth with limited iron [27-29,31]. The DetR response regulator is required for virulence in Xoo [32] but not in Xcc [27]. Unlike Pseudomonas ColS-ColR, neither VgrS-VgrR nor DetS-DetR has been implicated in the control of lipid A remodeling enzyme synthesis.

Orthologs are genes derived from the most recent common ancestor of the lineages being considered [33], and orthologous gene products generally perform similar functions $[34,35]$. To advance understanding of the raxRH and adjacent genes (Figure 1), we determined their orthologous relationships with genes of known function from other genera. These determinations generated two conclusions: first, that the Xanthomonas RaxH-RaxR pair is orthologous to the Pseudomonas ColS-ColR pair, which regulates lipid A remodeling enzyme synthesis in response to excess $\mathrm{Zn}^{2+}$ [36,37]; second, that the Xanthomonas genes denoted here as ept $A$, lpxE, and $\operatorname{arn} T$ likely encode enzymes that remodel lipid A in response to cell envelope stress. These results suggest that the Xanthomonas RaxH-RaxR two-component system regulates expression of the arnT-lpxE-eptA gene cluster encoding lipid A remodeling enzymes.

\section{Materials and Methods}

\subsection{Sequence Analyses}

The BLAST programs [38,39] were used for database searches and for determining reciprocal best hits. Nucleotide and deduced amino acid sequences were edited and analyzed with the programs EditSeq ${ }^{\mathrm{TM}}$ and MegAlign ${ }^{\mathrm{TM}}$ (version 14.1.0), DNASTAR, Madison, WI, USA. The Integrated Microbial Genomes interface [40] was used to compare genome segments from different species in order to analyze genome neighborhoods.

Xanthomonas genes described here in detail are from Xoo strain PXO99A (GenBank accession NC_010717.2) except as noted otherwise. Genes, locus tags and accession numbers are presented in Table S1. 


\subsection{Ortholog Identification}

Orthologous genes were identified initially by analyzing their predicted amino acid sequences for reciprocal BLASTP best hits $[34,35]$ using default parameters for database BLASTP searches [41] (expect $=10$; word size $=6$; matrix $=$ BLOSUM62; gap costs $=$ existence 11, extension 1; no compositional adjustments). Initial searches focused on comparisons between genes from Xoo and from Pseudomonas aeruginosa, a well-annotated close relative [42]. Other species and genera were examined as needed. Candidate orthologous pairs were then evaluated to ensure that they have similar lengths, that sequence similarity extends throughout most of their lengths, and that they have similar domain compositions. Candidates were further examined for the presence of conserved and functionally-important residues and for genome neighborhood.

Pairwise comparisons generated for Table 1 were performed with the pairwise BLASTP function using default parameters (expect $=0.05$; word size $=3$; matrix $=$ BLOSUM62; gap costs $=$ existence 11 , extension 1 ; conditional compositional score matrix adjustment).

Table 1. Ortholog sequence identity and coverage in pairwise alignments.

\begin{tabular}{|c|c|c|c|c|c|c|c|c|}
\hline Symbol $^{1}$ & Query $^{2}$ & Length & From & To & Cover & Subject & Identity & Gaps \\
\hline \multirow{4}{*}{ EptA } & Xoo & 556 & 24 & 556 & $96 \%$ & Pae & $45 \%$ & $1 \%$ \\
\hline & Pae & 567 & 6 & 544 & $95 \%$ & Xoo & $45 \%$ & $1 \%$ \\
\hline & Xoo & 556 & 22 & 549 & $95 \%$ & $\mathrm{Nmb}$ & $38 \%$ & $1 \%$ \\
\hline & $\mathrm{Nmb}$ & 544 & 7 & 540 & $98 \%$ & Xoo & $38 \%$ & $2 \%$ \\
\hline \multirow{4}{*}{ LpxE } & Xoo & 254 & 47 & 251 & $80 \%$ & Pae & $33 \%$ & $1 \%$ \\
\hline & Pae & 264 & 16 & 232 & $82 \%$ & Xoo & $33 \%$ & $2 \%$ \\
\hline & Xoo & 254 & 107 & 169 & $24 \%$ & Ret & $29 \%$ & $7 \%$ \\
\hline & Ret & 244 & 103 & 215 & $46 \%$ & Xoo & $32 \%$ & $11 \%$ \\
\hline \multirow{2}{*}{ ArnT } & Xoo & 577 & 30 & 336 & $53 \%$ & Pae & $31 \%$ & $8 \%$ \\
\hline & Pae & 549 & 40 & 345 & $56 \%$ & Xoo & $32 \%$ & $8 \%$ \\
\hline \multirow{2}{*}{$\operatorname{ArnC}^{3}$} & Xoo & 240 & 6 & 212 & $86 \%$ & Pae & $30 \%$ & $2 \%$ \\
\hline & Pae & 339 & 9 & 214 & $60 \%$ & Xoo & $30 \%$ & $2 \%$ \\
\hline \multirow{2}{*}{ FlmF1 4} & Xoo & 348 & 17 & 320 & $87 \%$ & Fno & $38 \%$ & $0 \%$ \\
\hline & Fno & 314 & 9 & 312 & $96 \%$ & Xoo & $38 \%$ & $0 \%$ \\
\hline
\end{tabular}

${ }^{1}$ Locus tags and accession numbers are in Table S1. ${ }^{2}$ Fno, Francisella novicida U112; Nmb, Neisseria meningitidis MC58; Ret, Rhizobium etli (leguminosarum) CFN42; Pae, Pseudomonas aeruginosa PAO1; Xoo, Xanthomonas oryzae pv. oryzae PXO99A. ${ }^{3}$ Xoo gene PXO_RS22265. ${ }^{4}$ Xoo gene PXO_RS14680.

\subsection{Predicted Transmembrane Helices}

Sequences were evaluated in the TMHMM Server v. 2.0 accessed through the Danish Technical University (http:/ / www.cbs.dtu.dk/services/TMHMM/, accessed on 14 April 2021). Predictions were refined by manual adjustment as necessary.

\section{Results}

\subsection{The gcvP-minCDE Region in the Xoo Strain PXO99A Genome}

The raxX-raxSTAB gene cluster apparently has been gained and lost multiple times during Xanthomonas speciation [8]. In all cases identified [8], this cluster is located in the same genome neighborhood, between the $g_{c v P}$ gene encoding a subunit of glycine dehydrogenase [43] on one side, and the $\min C D E$ operon encoding proteins required for cell division [44] on the other (Figure 1). The gene denoted as " $m f_{s} X$ " is predicted to encode a major facilitator subfamily permease [8]. The eptA, lpxE, and $\operatorname{arnT}$ genes are predicted to encode enzymes involved in lipid A remodeling, as described below (Sections 3.3-3.5).

The ace gene, identified first in Xac, encodes a dipeptidyl-carboxypeptidase homologous to mammalian ACE (angiotensin converting enzyme). Xac ACE enzyme efficiently digests mammalian ACE substrates such as angiotensin [45], although the authentic substrate(s) and physiological function(s) for bacterial ACE are not known. ace gene homologs 
are distributed throughout diverse bacterial phyla [45], and gene neighborhoods are not conserved across different genera (not shown).

The raxR-raxH and lpxE-eptA gene pairs have overlapping termination and initiation codons (ATGTCTAA and ATGA, respectively). Such overlaps indicate that the two gene products function together [46]. Otherwise, the $\operatorname{raxR}$-arnT intergenic region is $218 \mathrm{nt}$, the arnT-lpxE intergenic region is $99 \mathrm{nt}$, and the eptA-ace intergenic region is $111 \mathrm{nt}$ (Figure 1).

\subsection{Evidence That Xanthomonas RaxH-RaxR and Pseudomonas ColS-ColR Are Orthologous Pairs}

The two-component regulatory systems considered here all resemble the model EnvZOmpR pair that controls outer membrane porin synthesis in Escherichia coli [17,47]. In EnvZ-OmpR-type systems, the sensor protein comprises an amino-terminal periplasmic signal input domain and a carboxyl-terminal cytoplasmic transmitter module with histidine autokinase activity. The response regulator protein has amino-terminal phospho-accepting receiver and carboxyl-terminal DNA-binding domains. About 11 distinct OmpR-type response regulators [48] are conserved across different Xanthomonas spp. [49,50]. Of these, three cognate sensors have EnvZ-type transmitter sequences (HPK2 family [51]): RaxH, VgrS, and DetS. All three sensors also have been denoted as ColS (see Introduction), based on sequence similarities across the transmitter domains.

Three criteria indicate that the Xanthomonas RaxH-RaxR pair is orthologous to the Pseudomonas ColS-ColR pair [34,35]. First, the RaxH and Pseudomonas ColS periplasmic domain sequences display virtually identical size and predicted topology, even though they share only $20 \%$ identical residues (Figure 2 and Figure S1). The other two candidate ColS orthologs (VgrS and DetS) are predicted to adopt similar topologies, but their periplasmic domain sequences are different lengths (Figure 2 and not shown).

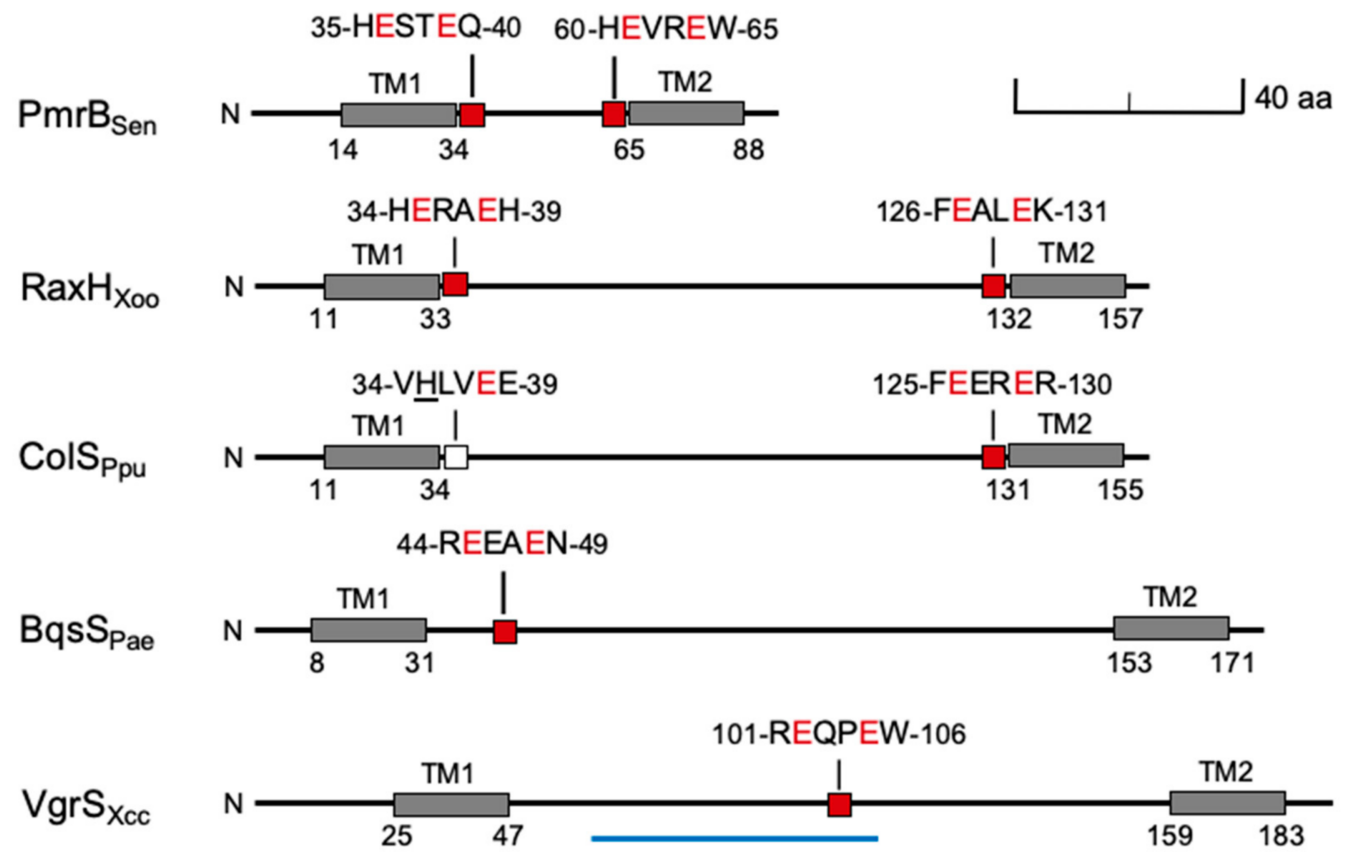

Figure 2. Periplasmic domain schematic structures for selected sensor proteins. Drawn to scale. The amino-terminal sequences are illustrated through the second of two transmembrane (TM) helices, shown as gray filled boxes. Numbers show positions of specific residues. The conserved ExxE motifs are shown as red-filled boxes, with the corresponding sequences above. The variant HxxE motif in ColS is shown as a white box. The blue line under the Xcc VgrS periplasmic domain shows the extent of a conserved sequence substitution in the Xoo sequence that removes the ExxE motif. Sen, Salmonella enterica LT2, Xoo, Xanthomonas oryzae pv. oryzae PXO99A , Ppu, Pseudomonas pudita KT2440, Pae, Pseudomonas aeruginosa PAO1, Xcc, Xanthomonas campestris pv. campestris 8004. See text for references. 
It should be noted that relatively low sequence identity between orthologous sensor periplasmic domains is typical. For example, the PhoQ sensors from P. aeruginosa [52] and Xoo [53] share only $25 \%$ sequence identity between the periplasmic domains, in contrast to $42 \%$ between the transmitter domains and $56 \%$ between the corresponding PhoP response regulators (alignments not shown).

Second, the ColS sequence includes the critical metal ion-binding ExxE (Glu-X-X-Glu) motif, just proximal to the second transmembrane helix, which is required for responses to $\mathrm{Fe}^{3+}, \mathrm{Zn}^{2+}$ and other metal ions [36]. This motif is at the same position in RaxH (Figure 2 and Figure S1), whereas the VgrS Fe ${ }^{3+}$-binding ExxE motif [54] is in the middle of the periplasmic domain sequence (Figure 2). (The DetS periplasmic domain sequence does not contain an ExxE motif.) For comparison, Figure 2 depicts periplasmic domains from two other ExxE motif-containing sensors, Salmonella enterica PmrB, which signals in response to excess $\mathrm{Fe}^{3+}$ or $\mathrm{Al}^{3+}$ [55], and P. aeruginosa BqsS, which signals in response to excess $\mathrm{Fe}^{2+}[56]$.

Remarkably, the RaxH sequence also includes a second ExxE motif, just distal to the first transmembrane helix, that is not conserved in ColS sequences (Figure 2 and Figure S1). In this respect, the RaxH sequence is similar to that of PmrB [55] (Figure 2). These differences in ExxE motif numbers and locations imply differences in binding specificity and/or affinities for different metal ions.

The third criterion for assigning RaxH-RaxR and ColS-ColR as orthologous pairs comes from analyzing genome neighborhoods [35]. Both the Xanthomonas raxRH and Pseudomonas colRS genes are adjacent to the divergently transcribed lpxE ortholog (Section 3.6, below). These neighborhoods differ in that the Pseudomonas eptA and arnT genes are elsewhere in the genome. Nonetheless, in P. aeruginosa and P. putida, the ColS-ColR pair activates expression of the ept $A$ [37] and predicted $l p x E$ genes [36,57], and represses expression of the $\operatorname{arnT} T$-containing $\operatorname{arnB}$ operon [37], all in response to excess $\mathrm{Zn}^{2+}$. Accordingly, the Xanthomonas eptA-lpxE-arnT cluster immediately adjacent to the raxRH genes suggests independently that RaxH-RaxR and ColS-ColR control similar physiological functions [35].

\subsection{The Xanthomonas eptA Gene Is Predicted to Encode Lipid A Phosphoethanolamine Transferase}

Sections 3.3-3.5 concern the genes ept A, lpxE, and $\operatorname{arnT}$, predicted to encode lipid A remodeling enzymes and to be regulated by the RaxH-RaxR two-component system.

LPS consists of the membrane anchor lipid A connected through a core oligosaccharide to the polymorphic $\mathrm{O}$ antigen polysaccharide [58-60]. Lipid A in many gram-negative genera (including Xanthomonas) is an acylated $\beta-1^{\prime}, 6$-linked glucosamine disaccharide bis-phosphate [61-64] (Figure 3A). The phosphates at positions 1 and $4^{\prime}$ are bridged by $\mathrm{Mg}^{2+}$ ions, providing one of the LPS lateral interactions necessary to form the characteristic tight permeability barrier $[60,65]$.

As the outer membrane's external surface, LPS confers unique permeability properties while also providing targets for bacteriophage attachment, host pattern recognition, and antimicrobial peptides. Accordingly, LPS structures can be remodeled not only by changing the $\mathrm{O}$ antigen but also through modifications to the core oligosaccharide and lipid $\mathrm{A}$ components [58-60]. Lipid A remodeling enzyme synthesis is induced by certain disruptive envelope stresses, including cation imbalance and cationic antimicrobial peptides.

One widespread modification is catalyzed by lipid A phosphoethanolamine transferase (EptA enzyme), which acts in the periplasm to transfer phosphoethanolamine (P-EtN) from phosphatidylethanolamine to positions 1 and/or $4^{\prime}$ on the lipid A disaccharide [58] (Figure 3B). The Xoo putative EptA sequence shares ca. $40 \%$ identity over most of its length with the orthologous P. aeruginosa EptA sequence (Table 1). Sequence alignments (not shown) reveal that the Xoo putative EptA sequence includes critical residues identified in N. meningitidis EptA [66]: Glu-240, Thr-280, Asp-452 and His-453 (Glu-253, Thr-293, Asp-463 and His-464 in Xoo EptA), which form the $\mathrm{Zn}^{2+}$-binding active site, and disulfides formed by Cys residue pairs at positions 276-286, 327-331, 348-353, 402-410, and 499-540 (287-297, 338-342, 359-364, 413-421, and 510-549 in Xoo EptA). 


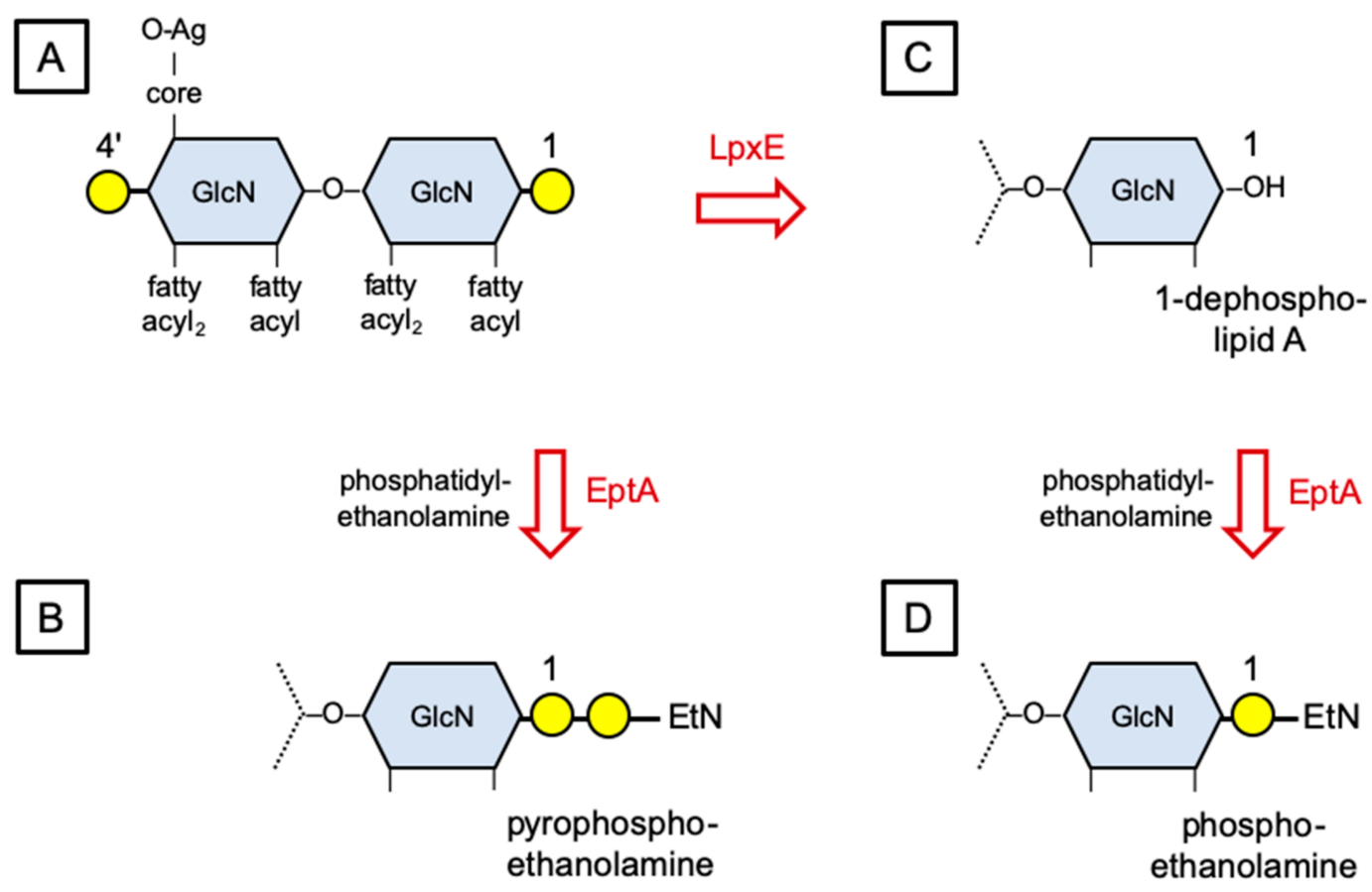

Figure 3. EptA (phosphoethanolamine transferase) and LpxE (lipid A 1-phosphatase) activities. (A) Lipid A schematic structure. The glucosamine disaccharide is decorated with six fatty acyl chains, the core oligosaccharide that ligates the polymorphic O-antigen (O-Ag) polysaccharide, and phosphate esters at positions 1 and 4'. (B) EptA enzyme adds phosphoethanolamine (P-EtN) to form a pyrophosphoethanolamine moiety. Only one glucosamine from the lipid A disaccharide is shown, but the same reaction also can occur at the $4^{\prime}$ position. (C) LpxE enzyme removes phosphate-1. (D) EptA enzyme adds P-EtN to form a phosphoethanolamine moiety. See text for references.

Lipid A from wild-type Xanthomonas campestris pv. campestris (Xcc) has undetectable EtN [63], whereas lipid A from a nonpathogenic rfaX mutant displays nonstoichiometric substitution with EtN at positions 1 and /or $4^{\prime}$ on the lipid A disaccharide [67]. The rfaX lesion generates LPS with a severely truncated core oligosaccharide, and so the resulting outer membrane disruption likely induces EptA synthesis [67]. Lipid A with linked EtN also has been detected in X. campestris pv. pruni [68], Xac [61], and Xoo [62], although not in $X$. fragariae [68] or X. translucens pv. translucens [64]. These results provide evidence that the Xoo putative EptA enzyme is synthesized and active (Figure 3).

\subsection{The Xanthomonas IpxE Gene Is Predicted to Encode Lipid A 1-phosphatase}

A second lipid A remodeling reaction is catalyzed by lipid A 1-phosphatase (LpxE enzyme), which functions in the periplasm [69,70] (Figure 3C). The Xoo putative LpxE sequence shares ca. $40 \%$ identity with the orthologous $P$. aeruginosa putative LpxE sequence (Table 1). These sequences share similar predicted membrane topology with the Rhizobium etli LpxE sequence $[69,70]$, each having six predicted transmembrane helices delimiting three periplasmic segments and four cytoplasmic segments (alignments not shown). Neither the structure nor the active site for LpxE enzyme has been determined. However, the Xoo putative LptE sequence includes several residues conserved in R. etli LpxE thought to be important for catalysis [69]: Lys-123, Pro-131, Pro-155, Gly-157, His-158 and His-197 (Lys-127, Pro-135, Pro-164, Gly-166, His-167, and His-213 in Xoo LpxE).

Some LpxE homologs have phosphatase activity on substrates other than lipid A [69,70]. Three lines of evidence support the hypothesis that the Xoo putative LpxE enzyme is lipid A 1-phosphatase. First, Helicobactri pylori EptA and LpxE enzymes are expressed from the eptA-lpxE operon [71], revealing a shared genome neighborhood. Recall that the Xoo lpxE and eptA genes overlap, indicating likely translational coupling (Figure 1; Section 3.1, above). 
Second, this genetic association reflects functional association, as H. pylori LpxE removes the lipid A 1-phosphate before EptA adds P-EtN, thereby forming a monophosphoethanolamine (P-EtN) moiety [72] (Figure 3C,D). In many other studied genera, P-EtN is added to the existing phosphate group, thereby forming a pyrophosphoethanolamine (PP-EtN) moiety [58,60] (Figure 3B). Strikingly, lipid A from Xac is a mixture wherein some molecules contain two PP-EtN moieties and others contain one PP-EtN and one P-EtN [61], providing evidence that $\mathrm{Xac}$ lipid A has been dephosphorylated in some cases before P-EtN addition.

Third, H. pylori and R. etli both synthesize dephospho-lipid A through LpxE (and LpxF) activities [73,74]. Some lipid A molecules from X. campestris pv. pruni are dephosphorylated [68], providing evidence that the Xanthomonas putative LpxE enzyme is synthesized and active (Figure 3). In H. pylori and R. etli, LpxE-dependent lipid A 1-dephosphorylation confers some resistance to antimicrobial peptides [71,75], although higher-level resistance requires LpxF-dependent lipid A 4'-dephosphorylation as well [73,74].

\subsection{The Xanthomonas arnT Gene Is Predicted to Encode Lipid A Glycosyl Transferase}

A third lipid A remodeling reaction is catalyzed by lipid A glycosyl transferase (ArnT enzyme), which functions in the periplasm to transfer 4-amino-4-deoxy-L-arabinose (Ara4N) from its undecaprenyl phosphate carrier to the phosphate at either end of the lipid A disaccharide [58-60]. The enzyme comprises an amino-terminal domain with 13 transmembrane helices and a carboxyl-terminal periplasmic domain whose sequence is poorly-conserved [76,77]. The Xoo putative ArnT sequence shares ca. $30 \%$ identity with the orthologous P. aeruginosa ArnT sequence over the amino-terminal half (Table 1), similar to other ArnT sequence comparisons [76,77]. Sequence alignments (not shown) reveal that the Xoo putative ArnT sequence includes critical residues identified in Cupriavidus metallidurans ArnT [76]: Glu-84, Lys-85, Arg-270 and Tyr-345 (Glu-70, Lys-71, Arg-264 and Tyr-335 in Xoo ArnT), all involved in coordinating the phosphate group of the undecaprenyl carrier, and the ion pairs Asp-55/Arg-58 and Asp-158/Lys-203 (Asp-41/Arg-44 and Asp-144/Lys-185 in Xoo ArnT), which orient the lipid A phosphate for catalysis.

ArnT enzyme first was identified and characterized in enterobacteria, where it is expressed from the arnBCADTEF operon [55]. Besides arnT, the remaining six arn genes encode enzymes that synthesize and translocate the Ara4N-undecaprenyl phosphate sugar donor for ArnT catalysis [78]. However, in some other species, the ArnT enzyme instead transfers galactosamine, glucosamine, or glucose [79-81]. For example, Francisella novicida encodes two homologs of the enterobacterial $\operatorname{arnC}$ gene, encoding undecaprenyl phosphate sugar transferase that instead are specific for galactosamine (FlmF2) or glucose (FlmF1) [82].

The enzyme responsible for making the putative undecaprenyl phosphate sugar substrate for Xanthomonas ArnT enzyme is not clear. At least two genes, both unlinked to the gcoP-minCDE cluster, potentially encode ArnC-like enzymes. Gene PXO_RS22265 encodes a protein ca. $30 \%$ identical to $P$. aeruginosa ArnC, although it is only about two-thirds as long (Table 1). This gene is in a cluster between PXO_RS22260, which encodes a predicted sugar-nucleotide epimerase, and PXO_RS22270, which encodes a ca. 100 residue protein homologous to a biochemically-uncharacterized amino-terminal domain in the LpxB lipid A-disaccharide synthase from Chlamydia and related genera (accession WP_009873791.1). Indeed, PXO_RS22265 and PXO_RS22270 homologs are linked to arnT genes in other species (Section 3.6 below), suggesting that they encode functions involved in lipid A remodeling. However, these genes also are present in species, such as clade 1 Xanthomonas spp., for which we did not identify an arnT ortholog (Section 3.6 below). Separately, gene PXO_RS14680 encodes a protein ca. 37\% identical to the F. novicida FlmF1 and FlmF2 sequences (Table 1). However, the adjacent gene PXO_RS14685 encodes an enzyme likely involved in peptidoglycan biosynthesis, so the PXO_RS14680-encoded protein may function in this process instead.

Thus, it is plausible that the Xanthomonas ArnT enzyme catalyzes transfer of a sugar other than Ara4N to lipid A. Nevertheless, to our knowledge, the only reported modifica- 
tions to Xanthomonas lipid A disaccharide phosphates are the dephosphorylation and the P-EtN and PP-EtN moieties described above. Accordingly, predicted function(s) for the Xoo putative ArnT enzyme are unspecified. Perhaps lipid A analysis from cultures grown under different conditions will identify a plausible ArnT-dependent modification.

\section{6. raxRH Gene Neighborhoods in Members of the Order Xanthomonadales (Lysobacterales)}

Expanding on our prior analysis [8], we compared the gcvP-minCDE regions across the range of Xanthomonas spp. There were 31 correctly-named Xanthomonas spp. as of 20 May 2021 [83]. We used the Integrated Microbial Genomes platform [40] to examine 41 genomes, with each correctly-named Xanthomonas species included at least once, to determine their $\operatorname{rax} R H$ gene neighborhoods (Table S2). The gcvP-minCDE region is virtually identical in each case (not shown), with two exceptions. First, some strains have the raxX-raxSTAB gene cluster between genes $g c v P$ and " $m f s X$ " (Figure 1), whereas others do not [8] (Table S2). Second, the relatively small number of strains from clade 1 [1,2] (Table S2) specifically lack only the arnT gene (Figure S2).

This phylogenetic distribution indicates that the complete $g c v P$-minCDE region (excepting the $\operatorname{raxX}$-raxSTAB gene cluster [8]) was not acquired recently through lateral gene transfer [84]. A separate, relatively simple criterion to examine this point is provided by the $\mathrm{G}+\mathrm{C}$ percentage, which often differs in laterally transferred genes [84]. In Xoo PXO99 ${ }^{\mathrm{A}}$, the $\mathrm{G}+\mathrm{C}$ percentage is relatively constant across the $g c v P$-min $C D E$ region (including the raxX-raxSTAB genes) and close to the median value for the entire genome: $63.7 \%$ (Figure S3).

Next, we used BLAST to search for homologs of the Xoo PXO99 A RaxH periplasmic domain sequence in other species from the order Xanthomonadales (renamed as Lysobacterales [83]). This search identified sequences from a variety of genera in the family Xanthomonadaceae (renamed as Lysobacteraceae [83]) and two genera from the family Rhodanobacteraceae (Table S1). The alignment of representative RaxH periplasmic domain sequences (Figure S1) shows that all share an overall length, predicted membrane topology, and conserved sequence features with Xoo RaxH. Notably, however, the TM2-proximal ExxE motif is not fully conserved, with the first Glu replaced by Gln, His, or Thr in some sequences (Figure S1 and not shown).

Finally, we examined $\operatorname{rax} R H$ gene neighborhoods for these and related strains. In each case, the raxRH genes are adjacent to one or another combination of the $\operatorname{arnT}$, lpxE, and eptA genes, reinforcing the association of the RaxH-RaxR two-component regulatory system with functions for LPS remodeling (Figure S2).

\section{Discussion}

\subsection{RaxH-RaxR and ColS-ColR Are Orthologous Two-Component Regulatory System Pairs}

Sequence comparisons between different phylogenetic groups can provide indispensable guidance for predicting gene functions. However, useful predictions depend upon accurate ortholog assignments [34,35]. Otherwise, genes with the same designations might be considered to have the same functions in different genera, potentially obscuring meaningful differences.

The ColS-ColR two-component regulatory system in Pseudomonas spp. responds to metal ions such as $\mathrm{Zn}^{2+}$ to control genes whose products remodel lipid A [18,19,36,37,57]. In Xanthomonas spp., the designation ColS-ColR has often [27-30] but not always [49,54,85] been applied to the VgrS-VgrR two-component regulatory system that controls a variety of virulence-related functions. However, evidence presented here suggests that the Xanthomonas RaxH and RaxR proteins are the true orthologs of ColS and ColR. Therefore, conflating Xanthomonas VgrS-VgrR with Pseudomonas ColS-ColR is potentially misleading, especially since the two regulatory systems appear to control different functions.

Although the RaxH and ColS sequences share overall similarities, they may have potential functional differences, for example in the number of ExxE motifs (Figure S1). Therefore, we recommend that the ColS and ColR designations no longer be applied to 
Xanthomonas two-component regulatory systems, and that the appropriate Rax, Vgr, and Det designations be used instead.

\subsection{Two-Component Regulatory Systems Regulate Lipid A Remodeling}

In other species, lipid A remodeling enzyme synthesis is controlled both directly and indirectly by multiple two-component regulatory systems. For example, S. enterica ept $A$ and $\operatorname{arnT}$ gene expression is activated indirectly by the PhoQ-PhoP pair in response to limiting $\mathrm{Mg}^{2+}$, and directly by the PmrB-PmrA pair in response to excess $\mathrm{Fe}^{3+}$ [55]. $P$. aeruginosa regulation is more complex, with five two-component regulatory systems to control lipid A remodeling enzyme synthesis in response to limiting $\mathrm{Mg}^{2+}$ (PhoQ-PhoP and PmrB-PmrA), excess $\mathrm{Zn}^{2+}$ (ColS-ColR), and antimicrobial peptides (CprS-CprR, ParS-ParR, and PmrB-PmrA) [86] found.

In comparison to S. enterica and P. aeruginosa, Xanthomonas spp. encode a distinct subset of two-component regulatory systems implicated in lipid A remodeling. The PhoQPhoP two-component regulatory system is encoded by all three genera [53,86], emphasizing its central role in the response to limiting $\mathrm{Mg}^{2+}$ [87]. By contrast, the PmrB-PmrA and RaxH-RaxR (ColS-ColR orthologs) pairs are absent from Xanthomonas spp. and S. enterica, respectively, and the CprS-CprR and ParS-ParR pairs are absent from both [31,50]. Thus, conservation of RaxH-RaxR (ColS-ColR orthologs) plus PhoQ-PhoP implies that lipid A regulation in Xanthomonas spp. comprises a subset of the complex P. aeruginosa network.

The RaxH-RaxR pair was characterized and named in the context of raxSTAB operon expression [12]. Nevertheless, Rax phenotypes conferred by raxH and rax $R$ null alleles are subtle, at least under the conditions studied, and potentially result from indirect effects. Better understanding of Xanthomonas two-component regulatory networks is necessary to define the relationship between the RaxH-RaxR pair and $\operatorname{raxX}$-raxSTAB regulation.

\subsection{Phenotypes Resulting from EptA-, LpxE-, and ArnT-Catalyzed Lipid A Remodeling}

The outer membrane permeability barrier depends on strong lateral interactions between LPS molecules, mediated in large part by $\mathrm{Mg}^{2+} \mathrm{Or} \mathrm{Ca}^{2+}$ ions that bridge phosphates in adjacent lipid A molecules [65]. In the mammalian pathogen S. enterica, limiting $\mathrm{Mg}^{2+}$ encountered during infection [88] induces EptA and ArnT synthesis for lipid A remodeling [55]. The resulting positively charged moieties counteract the phosphate negative charge partially (EtN) or fully (Ara4N), thereby reducing the $\mathrm{Mg}^{2+}$ dependence for LPS function [65]. By influencing LPS lateral interactions, different types of lipid A remodeling differentially affect the outer membrane structure, resilience, and permeability [65].

Lipid A remodeling confers two additional phenotypes, cation resistance and immune evasion [60]. First, LPS remodeled with EtN and/or Ara4N is more resistant to diverse toxic cations, including metals such as $\mathrm{Fe}^{3+}$ and antimicrobial peptides such as polymyxins [55]. EtN-mediated resistance to antimicrobial peptides is relatively weak compared to that conferred by Ara $4 \mathrm{~N}$ in both S. enterica [89] and P. aeruginosa [37,90], reflecting differences in molecular mass (EtN = $61 \mathrm{Da}$; Ara4N = $149 \mathrm{Da})$ and degrees of negative charge compensation [65]. Further variation comes from using PP-EtN vs P-EtN (Figure 3B vs. Figure 3D) or sugars other than Ara4N [79,80]. Plants also synthesize cationic antimicrobial peptides, and at least one of these induces ArnT synthesis in P. aeruginosa [91].

The second lipid A remodeling phenotype concerns interactions between LPS and host innate immune systems. In mammals, lipid A binds the TLR4/MD2 (Toll-like receptor 4 /myeloid differentiation factor 2) complex that controls innate immune responses to lipid A $[92,93]$. Binding involves both the fatty acyl chains and the phosphates, and so remodeled lipid A forms are recognized poorly by the TLR4/MD2 complex [94]. Notably, modifications involving phosphates 1 and $4^{\prime}$ influence TLR4/MD2 recognition and signaling [73,81,95-97], and appear to help host cells differentiate between pathogenic and commensal species [98].

Plant receptors for LPS molecules are yet to be identified. The Arabidopsis thaliana LORE receptor-like kinase, previously suggested to detect lipid A [99], instead responds 
to co-purified medium-chain 3-hydroxy fatty acid metabolites [100]. Nevertheless, plant recognition of LPS is a prominent feature of the innate response to bacteria $[63,99,101]$. Although plant-associated bacteria remodel their lipid A upon exposure to antimicrobial peptides [91], specific roles for lipid A and its remodeling are not defined. Xanthomonas spp. provide relatively simple models to evaluate roles for lipid A and its remodeling in a broad range of bacterium-plant contexts.

Supplementary Materials: The following are available online at https: / www.mdpi.com/article / 10.3390/microorganisms9071458/s1, Figure S1, Periplasmic domains from select RaxH and ColS sequences; Figure S2, raxRH gene neighborhoods in members of the order Lysobacterales (formerly Xanthomonadales); Figure S3, Percent G+C across the gcvP-minCDE region in Xoo PXO99A; Table S1, Locus tags and accession numbers; Table S2, Genome sequences used for gene neighborhood analysis.

Author Contributions: Analysis, V.S.; writing—original draft preparation, V.S.; writing-review and editing, P.C.R.; funding acquisition, P.C.R. Both authors have read and agreed to the published version of the manuscript.

Funding: This study was supported by Public Health Service grant GM122968 to P.C.R. from the National Institute of General Medical Sciences.

Institutional Review Board Statement: Not applicable.

Informed Consent Statement: Not applicable.

Data Availability Statement: All data are presented in the paper.

Acknowledgments: We thank Anna Joe and Saul Burdman for commenting on the manuscript. We are grateful to our laboratory colleagues for their interest, thoughtful discussion and support.

Conflicts of Interest: The authors declare no conflict of interest. The funders had no role in the design of the study; in the collection, analyses, or interpretation of data; in the writing of the manuscript, or in the decision to publish the results.

\section{References}

1. Jacques, M.A.; Arlat, M.; Boulanger, A.; Boureau, T.; Carrere, S.; Cesbron, S.; Chen, N.W.; Cociancich, S.; Darrasse, A.; Denance, N.; et al. Using ecology, physiology, and genomics to understand host specificity in Xanthomonas. Annu. Rev. Phytopathol. 2016, 54, 163-187. [CrossRef] [PubMed]

2. Timilsina, S.; Potnis, N.; Newberry, E.A.; Liyanapathiranage, P.; Iruegas-Bocardo, F.; White, F.F.; Goss, E.M.; Jones, J.B. Xanthomonas diversity, virulence and plant-pathogen interactions. Nat. Rev. Microbiol. 2020, 18, 415-427. [CrossRef] [PubMed]

3. Niño-Liu, D.O.; Ronald, P.C.; Bogdanove, A.J. Xanthomonas oryzae pathovars: Model pathogens of a model crop. Mol. Plant Pathol. 2006, 7, 303-324. [CrossRef] [PubMed]

4. Song, W.Y.; Wang, G.L.; Chen, L.L.; Kim, H.S.; Pi, L.Y.; Holsten, T.; Gardner, J.; Wang, B.; Zhai, W.X.; Zhu, L.H.; et al. A receptor kinase-like protein encoded by the rice disease resistance gene, Xa21. Science 1995, 270, 1804-1806. [CrossRef] [PubMed]

5. Pruitt, R.N.; Schwessinger, B.; Joe, A.; Thomas, N.; Liu, F.; Albert, M.; Robinson, M.R.; Chan, L.J.; Luu, D.D.; Chen, H.; et al. The rice immune receptor XA21 recognizes a tyrosine-sulfated protein from a Gram-negative bacterium. Sci. Adv. 2015, 1, e1500245. [CrossRef] [PubMed]

6. Pruitt, R.N.; Joe, A.; Zhang, W.; Feng, W.; Stewart, V.; Schwessinger, B.; Dinneny, J.R.; Ronald, P.C. A microbially derived tyrosine-sulfated peptide mimics a plant peptide hormone. New Phytol. 2017, 215, 725-736. [CrossRef] [PubMed]

7. Ronald, P.; Joe, A. Molecular mimicry modulates plant host responses to pathogens. Ann. Bot. 2018, 121, 17-23. [CrossRef]

8. Liu, F.; McDonald, M.; Schwessinger, B.; Joe, A.; Pruitt, R.; Erickson, T.; Zhao, X.; Stewart, V.; Ronald, P.C. Variation and inheritance of the Xanthomonas raxX-raxSTAB gene cluster required for activation of XA21-mediated immunity. Mol. Plant Pathol. 2019, 20, 656-672. [CrossRef]

9. da Silva, F.G.; Shen, Y.; Dardick, C.; Burdman, S.; Yadav, R.C.; de Leon, A.L.; Ronald, P.C. Bacterial genes involved in type I secretion and sulfation are required to elicit the rice XA21-mediated innate immune response. Mol. Plant Microbe Interact. 2004, 17, 593-601. [CrossRef] [PubMed]

10. Han, S.W.; Lee, S.W.; Bahar, O.; Schwessinger, B.; Robinson, M.R.; Shaw, J.B.; Madsen, J.A.; Brodbelt, J.S.; Ronald, P.C. Tyrosine sulfation in a Gram-negative bacterium. Nat. Commun. 2012, 3, 1153. [CrossRef] [PubMed]

11. Luu, D.D.; Joe, A.; Chen, Y.; Parys, K.; Bahar, O.; Pruitt, R.; Chan, L.J.G.; Petzold, C.J.; Long, K.; Adamchak, C.; et al. Biosynthesis and secretion of the microbial sulfated peptide RaxX and binding to the rice XA21 immune receptor. Proc. Natl. Acad. Sci. USA 2019, 116, 8525-8534. [CrossRef]

12. Burdman, S.; Shen, Y.; Lee, S.W.; Xue, Q.; Ronald, P. RaxH/RaxR: A two-component regulatory system in Xanthomonas oryzae pv. oryzae required for AvrXa21 activity. Mol. Plant Microbe Interact. 2004, 17, 602-612. [CrossRef] 
13. Stolov, A.; Valverde, A.; Ronald, P.; Burdman, S. Purification of soluble and active RaxH, a transmembrane histidine protein kinase from Xanthomonas oryzae pv. oryzae required for AvrXa21 activity. Mol. Plant Pathol. 2007, 8, 93-101. [CrossRef]

14. Albright, L.M.; Huala, E.; Ausubel, F.M. Prokaryotic signal transduction mediated by sensor and regulator protein pairs. Annu. Rev. Genet. 1989, 23, 311-336. [CrossRef]

15. Parkinson, J.S.; Kofoid, E.C. Communication modules in bacterial signaling proteins. Annu. Rev. Genet. 1992, $26,71-112$. [CrossRef]

16. Stock, J.B.; Ninfa, A.J.; Stock, A.M. Protein phosphorylation and regulation of adaptive responses in bacteria. Microbiol. Rev. 1989, 53, 450-490. [CrossRef]

17. Igo, M.M.; Ninfa, A.J.; Stock, J.B.; Silhavy, T.J. Phosphorylation and dephosphorylation of a bacterial transcriptional activator by a transmembrane receptor. Genes Dev. 1989, 3, 1725-1734. [CrossRef]

18. de Weert, S.; Dekkers, L.C.; Bitter, W.; Tuinman, S.; Wijfjes, A.H.; van Boxtel, R.; Lugtenberg, B.J. The two-component colR/S system of Pseudomonas fluorescens WCS365 plays a role in rhizosphere competence through maintaining the structure and function of the outer membrane. FEMS Microbiol. Ecol. 2006, 58, 205-213. [CrossRef]

19. Dekkers, L.C.; Bloemendaal, C.J.; de Weger, L.A.; Wijffelman, C.A.; Spaink, H.P.; Lugtenberg, B.J. A two-component system plays an important role in the root-colonizing ability of Pseudomonas fluorescens strain WCS365. Mol. Plant Microbe Interact. 1998, 11, 45-56. [CrossRef]

20. da Silva, A.C.; Ferro, J.A.; Reinach, F.C.; Farah, C.S.; Furlan, L.R.; Quaggio, R.B.; Monteiro-Vitorello, C.B.; Van Sluys, M.A.; Almeida, N.F.; Alves, L.M.; et al. Comparison of the genomes of two Xanthomonas pathogens with differing host specificities. Nature 2002, 417, 459-463. [CrossRef]

21. Lee, B.M.; Park, Y.J.; Park, D.S.; Kang, H.W.; Kim, J.G.; Song, E.S.; Park, I.C.; Yoon, U.H.; Hahn, J.H.; Koo, B.S.; et al. The genome sequence of Xanthomonas oryzae pathovar oryzae KACC10331, the bacterial blight pathogen of rice. Nucleic Acids Res. 2005, 33, 577-586. [CrossRef] [PubMed]

22. Moreira, L.M.; Almeida, N.F., Jr.; Potnis, N.; Digiampietri, L.A.; Adi, S.S.; Bortolossi, J.C.; da Silva, A.C.; da Silva, A.M.; de Moraes, F.E.; de Oliveira, J.C.; et al. Novel insights into the genomic basis of citrus canker based on the genome sequences of two strains of Xanthomonas fuscans subsp. aurantifolii. BMC Genom. 2010, 11, 238. [CrossRef] [PubMed]

23. Jalan, N.; Aritua, V.; Kumar, D.; Yu, F.; Jones, J.B.; Graham, J.H.; Setubal, J.C.; Wang, N. Comparative genomic analysis of Xanthomonas axonopodis pv. citrumelo $\mathrm{F} 1$, which causes citrus bacterial spot disease, and related strains provides insights into virulence and host specificity. J. Bacteriol. 2011, 193, 6342-6357. [CrossRef] [PubMed]

24. Kimbrel, J.A.; Givan, S.A.; Temple, T.N.; Johnson, K.B.; Chang, J.H. Genome sequencing and comparative analysis of the carrot bacterial blight pathogen, Xanthomonas hortorum pv. carotae M081, for insights into pathogenicity and applications in molecular diagnostics. Mol. Plant Pathol. 2011, 12, 580-594. [CrossRef]

25. Sharma, V.; Midha, S.; Ranjan, M.; Pinnaka, A.K.; Patil, P.B. Genome sequence of Xanthomonas axonopodis pv. punicae strain LMG 859. J. Bacteriol. 2012, 194, 2395. [CrossRef]

26. Midha, S.; Patil, P.B. Genomic insights into the evolutionary origin of Xanthomonas axonopodis pv. citri and its ecological relatives. Appl. Environ. Microbiol. 2014, 80, 6266-6279. [CrossRef]

27. Zhang, S.S.; He, Y.Q.; Xu, L.M.; Chen, B.W.; Jiang, B.L.; Liao, J.; Cao, J.R.; Liu, D.; Huang, Y.Q.; Liang, X.X.; et al. A putative colR $\mathrm{XC1049}$-colS $\mathrm{XC1050}_{\mathrm{T}}$ two-component signal transduction system in Xanthomonas campestris positively regulates $\mathrm{hrpC}$ and $\mathrm{hrpE}$ operons and is involved in virulence, the hypersensitive response and tolerance to various stresses. Res. Microbiol. 2008, 159, 569-578. [CrossRef]

28. Yan, Q.; Wang, N. The ColR/ColS two-component system plays multiple roles in the pathogenicity of the citrus canker pathogen Xanthomonas citri subsp. citri. J. Bacteriol. 2011, 193, 1590-1599. [CrossRef]

29. Subramoni, S.; Pandey, A.; Vishnu Priya, M.R.; Patel, H.K.; Sonti, R.V. The ColRS system of Xanthomonas oryzae pv. oryzae is required for virulence and growth in iron-limiting conditions. Mol. Plant Pathol. 2012, 13, 690-703. [CrossRef]

30. Fan, X.; Guo, J.; Zhou, Y.; Zhuo, T.; Hu, X.; Zou, H. The ColRS-regulated membrane protein gene XAC1347 is involved in copper homeostasis and hrp gene expression in Xanthomonas citri subsp. citri. Front. Microbiol. 2018, 9, 1171. [CrossRef]

31. Qian, W.; Han, Z.J.; Tao, J.; He, C. Genome-scale mutagenesis and phenotypic characterization of two-component signal transduction systems in Xanthomonas campestris pv. campestris ATCC 33913. Mol. Plant Microbe Interact. 2008, 21, 1128-1138. [CrossRef]

32. Nguyen, M.P.; Park, J.; Cho, M.H.; Lee, S.W. Role of DetR in defence is critical for virulence of Xanthomonas oryzae pv. oryzae. Mol. Plant Pathol. 2016, 17, 601-613. [CrossRef]

33. Fitch, W.M. Homology: A personal view on some of the problems. Trends Genet. 2000, 16, 227-231. [CrossRef]

34. Tatusov, R.L.; Koonin, E.V.; Lipman, D.J. A genomic perspective on protein families. Science 1997, 278, 631-637. [CrossRef]

35. Bork, P.; Dandekar, T.; Diaz-Lazcoz, Y.; Eisenhaber, F.; Huynen, M.; Yuan, Y. Predicting function: From genes to genomes and back. J. Mol. Biol. 1998, 283, 707-725. [CrossRef]

36. Ainsaar, K.; Mumm, K.; Ilves, H.; Horak, R. The ColRS signal transduction system responds to the excess of external zinc, iron, manganese, and cadmium. BMC Microbiol. 2014, 14, 162. [CrossRef]

37. Nowicki, E.M.; O’Brien, J.P.; Brodbelt, J.S.; Trent, M.S. Extracellular zinc induces phosphoethanolamine addition to Pseudomonas aeruginosa lipid A via the ColRS two-component system. Mol. Microbiol. 2015, 97, 166-178. [CrossRef] 
38. Altschul, S.F.; Gish, W.; Miller, W.; Myers, E.W.; Lipman, D.J. Basic local alignment search tool. J. Mol. Biol. 1990, 215, 403-410. [CrossRef]

39. Sayers, E.W.; Beck, J.; Bolton, E.E.; Bourexis, D.; Brister, J.R.; Canese, K.; Comeau, D.C.; Funk, K.; Kim, S.; Klimke, W.; et al. Database resources of the National Center for Biotechnology Information. Nucleic Acids Res. 2021, 49, D10-D17. [CrossRef]

40. Chen, I.A.; Markowitz, V.M.; Chu, K.; Palaniappan, K.; Szeto, E.; Pillay, M.; Ratner, A.; Huang, J.; Andersen, E.; Huntemann, M.; et al. IMG/M: Integrated genome and metagenome comparative data analysis system. Nucleic Acids Res. 2017, 45, D507-D516. [CrossRef]

41. Moreno-Hagelsieb, G.; Latimer, K. Choosing BLAST options for better detection of orthologs as reciprocal best hits. Bioinformatics 2008, 24, 319-324. [CrossRef]

42. Winsor, G.L.; Van Rossum, T.; Lo, R.; Khaira, B.; Whiteside, M.D.; Hancock, R.E.; Brinkman, F.S. Pseudomonas Genome Database: Facilitating user-friendly, comprehensive comparisons of microbial genomes. Nucleic Acids Res. 2009, 37, D483-D488. [CrossRef]

43. Stauffer, G.V. Regulation of serine, glycine, and one-carbon biosynthesis. EcoSal Plus 2004, 1. [CrossRef]

44. Kretschmer, S.; Schwille, P. Pattern formation on membranes and its role in bacterial cell division. Curr. Opin. Cell Biol. 2016, 38, 52-59. [CrossRef]

45. Riviere, G.; Michaud, A.; Corradi, H.R.; Sturrock, E.D.; Ravi Acharya, K.; Cogez, V.; Bohin, J.P.; Vieau, D.; Corvol, P. Characterization of the first angiotensin-converting like enzyme in bacteria: Ancestor ACE is already active. Gene 2007, 399, 81-90. [CrossRef]

46. Oppenheim, D.S.; Yanofsky, C. Translational coupling during expression of the tryptophan operon of Escherichia coli. Genetics 1980, 95, 785-795. [CrossRef]

47. Hall, M.N.; Silhavy, T.J. Genetic analysis of the ompB locus in Escherichia coli K-12. J. Mol. Biol. 1981, 151, 1-15. [CrossRef]

48. Galperin, M.Y. Structural classification of bacterial response regulators: Diversity of output domains and domain combinations. J. Bacteriol. 2006, 188, 4169-4182. [CrossRef] [PubMed]

49. Qian, W.; Han, Z.J.; He, C. Two-component signal transduction systems of Xanthomonas spp.: A lesson from genomics. Mol. Plant Microbe Interact. 2008, 21, 151-161. [CrossRef] [PubMed]

50. Bogdanove, A.J.; Koebnik, R.; Lu, H.; Furutani, A.; Angiuoli, S.V.; Patil, P.B.; Van Sluys, M.A.; Ryan, R.P.; Meyer, D.F.; Han, S.W.; et al. Two new complete genome sequences offer insight into host and tissue specificity of plant pathogenic Xanthomonas spp. J. Bacteriol. 2011, 193, 5450-5464. [CrossRef] [PubMed]

51. Grebe, T.W.; Stock, J.B. The histidine protein kinase superfamily. Adv. Microb. Physiol. 1999, 41, 139-227. [CrossRef]

52. Macfarlane, E.L.; Kwasnicka, A.; Ochs, M.M.; Hancock, R.E. PhoP-PhoQ homologues in Pseudomonas aeruginosa regulate expression of the outer-membrane protein OprH and polymyxin B resistance. Mol. Microbiol. 1999, 34, 305-316. [CrossRef]

53. Lee, S.W.; Jeong, K.S.; Han, S.W.; Lee, S.E.; Phee, B.K.; Hahn, T.R.; Ronald, P. The Xanthomonas oryzae pv. oryzae PhoPQ two-component system is required for AvrXA21 activity, hrpG expression, and virulence. J. Bacteriol. 2008, 190, $2183-2197$. [CrossRef]

54. Wang, L.; Pan, Y.; Yuan, Z.H.; Zhang, H.; Peng, B.Y.; Wang, F.F.; Qian, W. Two-component signaling system VgrRS directly senses extracytoplasmic and intracellular iron to control bacterial adaptation under iron depleted stress. PLoS Pathog. 2016, 12, e1006133. [CrossRef]

55. Chen, H.D.; Groisman, E.A. The biology of the PmrA/PmrB two-component system: The major regulator of lipopolysaccharide modifications. Annu. Rev. Microbiol. 2013, 67, 83-112. [CrossRef]

56. Kreamer, N.N.; Costa, F.; Newman, D.K. The ferrous iron-responsive BqsRS two-component system activates genes that promote cationic stress tolerance. Mbio 2015, 6, e02549. [CrossRef]

57. Kivistik, P.A.; Kivi, R.; Kivisaar, M.; Horak, R. Identification of ColR binding consensus and prediction of regulon of ColRS two-component system. BMC Mol. Biol. 2009, 10, 46. [CrossRef]

58. Raetz, C.R.; Reynolds, C.M.; Trent, M.S.; Bishop, R.E. Lipid A modification systems in gram-negative bacteria. Annu. Rev. Biochem. 2007, 76, 295-329. [CrossRef]

59. Whitfield, C.; Trent, M.S. Biosynthesis and export of bacterial lipopolysaccharides. Annu. Rev. Biochem. 2014, 83, 99-128. [CrossRef]

60. Simpson, B.W.; Trent, M.S. Pushing the envelope: LPS modifications and their consequences. Nat. Rev. Microbiol. 2019, 17, 403-416. [CrossRef]

61. Casabuono, A.; Petrocelli, S.; Ottado, J.; Orellano, E.G.; Couto, A.S. Structural analysis and involvement in plant innate immunity of Xanthomonas axonopodis pv. citri lipopolysaccharide. J. Biol. Chem. 2011, 286, 25628-25643. [CrossRef] [PubMed]

62. Di Lorenzo, F.; Palmigiano, A.; Silipo, A.; Desaki, Y.; Garozzo, D.; Lanzetta, R.; Shibuya, N.; Molinaro, A. The structure of the lipooligosaccharide from Xanthomonas oryzae pv. oryzae: The causal agent of the bacterial leaf blight in rice. Carbohydr. Res. 2016, 427, 38-43. [CrossRef]

63. Silipo, A.; Molinaro, A.; Sturiale, L.; Dow, J.M.; Erbs, G.; Lanzetta, R.; Newman, M.A.; Parrilli, M. The elicitation of plant innate immunity by lipooligosaccharide of Xanthomonas campestris. J. Biol. Chem. 2005, 280, 33660-33668. [CrossRef] [PubMed]

64. Steffens, T.; Duda, K.; Lindner, B.; Vorholter, F.J.; Bednarz, H.; Niehaus, K.; Holst, O. The lipopolysaccharide of the crop pathogen Xanthomonas translucens pv. translucens: Chemical characterization and determination of signaling events in plant cells. Glycobiology 2017, 27, 264-274. [CrossRef] [PubMed] 
65. Nikaido, H. Molecular basis of bacterial outer membrane permeability revisited. Microbiol. Mol. Biol. Rev. 2003, 67, 593-656. [CrossRef]

66. Wanty, C.; Anandan, A.; Piek, S.; Walshe, J.; Ganguly, J.; Carlson, R.W.; Stubbs, K.A.; Kahler, C.M.; Vrielink, A. The structure of the neisserial lipooligosaccharide phosphoethanolamine transferase A (LptA) required for resistance to polymyxin. J. Mol. Biol. 2013, 425, 3389-3402. [CrossRef] [PubMed]

67. Silipo, A.; Sturiale, L.; Garozzo, D.; Erbs, G.; Jensen, T.T.; Lanzetta, R.; Dow, J.M.; Parrilli, M.; Newman, M.A.; Molinaro, A. The acylation and phosphorylation pattern of lipid A from Xanthomonas campestris strongly influence its ability to trigger the innate immune response in Arabidopsis. ChemBioChem 2008, 9, 896-904. [CrossRef] [PubMed]

68. Silipo, A.; Molinaro, A.; Lanzetta, R.; Parrilli, M.; Lindner, B.; Holst, O. The structures of the lipid A moieties from the lipopolysaccharides of two phytopathogenic bacteria, Xanthomonas campestris pv. pruni and Xanthomonas fragariae. Eur. J. Org. Chem. 2004, 2004, 1336-1343. [CrossRef]

69. Karbarz, M.J.; Six, D.A.; Raetz, C.R. Purification and characterization of the lipid A 1-phosphatase LpxE of Rhizobium leguminosarum. J. Biol. Chem. 2009, 284, 414-425. [CrossRef]

70. Zhao, J.; An, J.; Hwang, D.; Wu, Q.; Wang, S.; Gillespie, R.A.; Yang, E.G.; Guan, Z.; Zhou, P.; Chung, H.S. The lipid A 1-phosphatase, LpxE, functionally connects multiple layers of bacterial envelope biogenesis. Mbio 2019, 10. [CrossRef]

71. Tran, A.X.; Whittimore, J.D.; Wyrick, P.B.; McGrath, S.C.; Cotter, R.J.; Trent, M.S. The lipid A 1-phosphatase of Helicobacter pylori is required for resistance to the antimicrobial peptide polymyxin. J. Bacteriol. 2006, 188, 4531-4541. [CrossRef]

72. Tran, A.X.; Karbarz, M.J.; Wang, X.; Raetz, C.R.; McGrath, S.C.; Cotter, R.J.; Trent, M.S. Periplasmic cleavage and modification of the 1-phosphate group of Helicobacter pylori lipid A. J. Biol. Chem. 2004, 279, 55780-55791. [CrossRef]

73. Cullen, T.W.; Giles, D.K.; Wolf, L.N.; Ecobichon, C.; Boneca, I.G.; Trent, M.S. Helicobacter pylori versus the host: Remodeling of the bacterial outer membrane is required for survival in the gastric mucosa. PLoS Pathog. 2011, 7, e1002454. [CrossRef]

74. Ingram, B.O.; Sohlenkamp, C.; Geiger, O.; Raetz, C.R. Altered lipid A structures and polymyxin hypersensitivity of Rhizobium etli mutants lacking the LpxE and LpxF phosphatases. Biochim. Biophys. Acta BBA Mol. Cell Biol. Lipids 2010, 1801, 593-604. [CrossRef]

75. Karbarz, M.J.; Kalb, S.R.; Cotter, R.J.; Raetz, C.R. Expression cloning and biochemical characterization of a Rhizobium leguminosarum lipid A 1-phosphatase. J. Biol. Chem. 2003, 278, 39269-39279. [CrossRef]

76. Petrou, V.I.; Herrera, C.M.; Schultz, K.M.; Clarke, O.B.; Vendome, J.; Tomasek, D.; Banerjee, S.; Rajashankar, K.R.; Belcher Dufrisne, M.; Kloss, B.; et al. Structures of aminoarabinose transferase ArnT suggest a molecular basis for lipid A glycosylation. Science 2016, 351, 608-612. [CrossRef]

77. Tavares-Carreon, F.; Patel, K.B.; Valvano, M.A. Burkholderia cenocepacia and Salmonella enterica ArnT proteins that transfer 4amino-4-deoxy-l-arabinose to lipopolysaccharide share membrane topology and functional amino acids. Sci. Rep. 2015, 5, 10773. [CrossRef]

78. Trent, M.S.; Ribeiro, A.A.; Lin, S.; Cotter, R.J.; Raetz, C.R. An inner membrane enzyme in Salmonella and Escherichia coli that transfers 4-amino-4-deoxy-L-arabinose to lipid A: Induction on polymyxin-resistant mutants and role of a novel lipid-linked donor. J. Biol. Chem. 2001, 276, 43122-43131. [CrossRef]

79. Marr, N.; Tirsoaga, A.; Blanot, D.; Fernandez, R.; Caroff, M. Glucosamine found as a substituent of both phosphate groups in Bordetella lipid A backbones: Role of a BvgAS-activated ArnT ortholog. J. Bacteriol. 2008, 190, 4281-4290. [CrossRef]

80. Wang, X.; Ribeiro, A.A.; Guan, Z.; Raetz, C.R. Identification of undecaprenyl phosphate-beta-D-galactosamine in Francisella novicida and its function in lipid A modification. Biochemistry 2009, 48, 1162-1172. [CrossRef]

81. Shah, N.R.; Albitar-Nehme, S.; Kim, E.; Marr, N.; Novikov, A.; Caroff, M.; Fernandez, R.C. Minor modifications to the phosphate groups and the C3' acyl chain length of lipid A in two Bordetella pertussis strains, BP338 and 18-323, independently affect Toll-like receptor 4 protein activation. J. Biol. Chem. 2013, 288, 11751-11760. [CrossRef]

82. Song, F.; Guan, Z.; Raetz, C.R. Biosynthesis of undecaprenyl phosphate-galactosamine and undecaprenyl phosphate-glucose in Francisella novicida. Biochemistry 2009, 48, 1173-1182. [CrossRef]

83. Parte, A.C.; Sarda Carbasse, J.; Meier-Kolthoff, J.P.; Reimer, L.C.; Göker, M. List of prokaryotic names with standing in nomenclature (LPSN) moves to the DSMZ. Int. J. Syst. Evol. Microbiol. 2020, 70, 5607-5612. [CrossRef]

84. Azad, R.K.; Lawrence, J.G. Detecting laterally transferred genes. Methods Mol. Biol. 2012, 855, 281-308. [CrossRef]

85. Deng, C.Y.; Zhang, H.; Wu, Y.; Ding, L.L.; Pan, Y.; Sun, S.T.; Li, Y.J.; Wang, L.; Qian, W. Proteolysis of histidine kinase VgrS inhibits its autophosphorylation and promotes osmostress resistance in Xanthomonas campestris. Nat. Commun. 2018, 9, 4791. [CrossRef]

86. Francis, V.I.; Stevenson, E.C.; Porter, S.L. Two-component systems required for virulence in Pseudomonas aeruginosa. FEMS Microbiol. Lett. 2017, 364. [CrossRef]

87. Groisman, E.A.; Hollands, K.; Kriner, M.A.; Lee, E.J.; Park, S.Y.; Pontes, M.H. Bacterial $\mathrm{Mg}^{2+}$ homeostasis, transport, and virulence. Annu. Rev. Genet. 2013, 47, 625-646. [CrossRef]

88. Cunrath, O.; Bumann, D. Host resistance factor SLC11A1 restricts Salmonella growth through magnesium deprivation. Science 2019, 366, 995-999. [CrossRef]

89. Lee, H.; Hsu, F.F.; Turk, J.; Groisman, E.A. The PmrA-regulated pmrC gene mediates phosphoethanolamine modification of lipid A and polymyxin resistance in Salmonella enterica. J. Bacteriol. 2004, 186, 4124-4133. [CrossRef] 
90. Liu, Y.Y.; Chandler, C.E.; Leung, L.M.; McElheny, C.L.; Mettus, R.T.; Shanks, R.M.Q.; Liu, J.H.; Goodlett, D.R.; Ernst, R.K.; Doi, Y. Structural modification of lipopolysaccharide conferred by mcr-1 in Gram-negative ESKAPE pathogens. Antimicrob. Agents Chemother. 2017, 61. [CrossRef]

91. Sathoff, A.E.; Lewenza, S.; Samac, D.A. Plant defensin antibacterial mode of action against Pseudomonas species. BMC Microbiol. 2020, 20, 173. [CrossRef] [PubMed]

92. Maeshima, N.; Fernandez, R.C. Recognition of lipid A variants by the TLR4-MD-2 receptor complex. Front. Cell Infect. Microbiol. 2013, 3, 3. [CrossRef]

93. Xiao, X.; Sankaranarayanan, K.; Khosla, C. Biosynthesis and structure-activity relationships of the lipid A family of glycolipids. Curr. Opin. Chem. Biol. 2017, 40, 127-137. [CrossRef]

94. Park, B.S.; Song, D.H.; Kim, H.M.; Choi, B.S.; Lee, H.; Lee, J.O. The structural basis of lipopolysaccharide recognition by the TLR4-MD-2 complex. Nature 2009, 458, 1191-1195. [CrossRef] [PubMed]

95. Chilton, P.M.; Embry, C.A.; Mitchell, T.C. Effects of differences in lipid A structure on TLR4 pro-inflammatory signaling and inflammasome activation. Front. Immunol. 2012, 3, 154. [CrossRef]

96. Coats, S.R.; Berezow, A.B.; To, T.T.; Jain, S.; Bainbridge, B.W.; Banani, K.P.; Darveau, R.P. The lipid A phosphate position determines differential host Toll-like receptor 4 responses to phylogenetically related symbiotic and pathogenic bacteria. Infect. Immun. 2011, 79, 203-210. [CrossRef]

97. Cullen, T.W.; Schofield, W.B.; Barry, N.A.; Putnam, E.E.; Rundell, E.A.; Trent, M.S.; Degnan, P.H.; Booth, C.J.; Yu, H.; Goodman, A.L. Antimicrobial peptide resistance mediates resilience of prominent gut commensals during inflammation. Science 2015, 347, 170-175. [CrossRef]

98. Munford, R.S. Sensing gram-negative bacterial lipopolysaccharides: A human disease determinant? Infect. Immun. 2008, 76, 454-465. [CrossRef]

99. Ranf, S. Immune sensing of lipopolysaccharide in plants and animals: Same but different. PLoS Pathog. 2016, 12, e1005596. [CrossRef]

100. Kutschera, A.; Dawid, C.; Gisch, N.; Schmid, C.; Raasch, L.; Gerster, T.; Schaffer, M.; Smakowska-Luzan, E.; Belkhadir, Y.; Vlot, A.C.; et al. Bacterial medium-chain 3-hydroxy fatty acid metabolites trigger immunity in Arabidopsis plants. Science 2019, 364, 178-181. [CrossRef]

101. Silipo, A.; Erbs, G.; Shinya, T.; Dow, J.M.; Parrilli, M.; Lanzetta, R.; Shibuya, N.; Newman, M.A.; Molinaro, A. Glyco-conjugates as elicitors or suppressors of plant innate immunity. Glycobiology 2010, 20, 406-419. [CrossRef] 